\title{
Forgotten Communication: Humans and Dogs in Curzio Malaparte's and Carlo Levi's Literature
}

\author{
José Maurício Saldanha Alvarez \\ Correspondence: Cultural Studies and Media Department, Universidade Federal Fluminense, Brasil.
}

Received: November 12, 2018 Accepted: December 19, 2018 Online Published: December 26, 2018

doi:10.5539/res.v11n1p14 URL: https://doi.org/10.5539/res.v11n1p14

\begin{abstract}
This paper analyzes the role of the dog in the work of two modern Italian writers, selecting from each of the texts in which they formulate a peculiar role for the animal represented in their works. The dog is sometimes capable of being the key that opens a magical world and becomes the counterpart to humanity, harboring the feelings that modernity and fascist politics displaced during the crucial time between 1922 and 1945.
\end{abstract}

Keywords: dog, animals, modernity, fascism, exile, Europe

\section{Animals and Humans: A Brief History of Their Relationship}

This essay will analyze the presence of animals in the works of two Italian writers, Curzio Malaparte (1898-1957) and Carlo Levi (1902-1975), who granted canine characters (Febo and Barone, respectively) starring roles, although they were given no narrative voices. These writings emerged in the crucial years between the rise and fall of fascism in Europe. It is not surprising that, given their political militancy and resistance to the authoritarian arbitrators, the two writers looked at animals as beings with deep knowledge, as beings capable of teaching people about existential qualities that had been lost in the course of modernity.

The purpose of this essay is to consider the works of two authors whose writing oscillates between narrative fiction and memoir, in which the dog plays the essential role of representing the future of humanity and serving as a teacher of life practices. To help situate the chosen works, we will present an argument that reveals the earliest relations between dogs and humans when the animals were highly revered. We will pass through modernity until the time of totalitarianism when Levi and Malaparte wrote their works, exalting the qualities of the dog before the fragility of human beings.

From antiquity, and especially in classical times, animals were considered almost divine, following gods and goddesses in their daily lives: the Roman god Silvanus, for example, was followed by a dog. The Middle Ages expressed an ambivalent attitude towards the dog. In the Christian West, the animal was transformed into a symbol of fidelity (Johns, 2008, p. 28), yet there was still a certain ambivalence towards it, moving between the dogs of God and the Hounds of Hell (Gibson, 2006, p. 393).

In the eighteenth century, during the Enlightenment, the French philosopher Condorcet (1743-1794) stated that reason had triumphed over obscurity, the past, its knowledge, and above all, over animals. Human beings were superior because they had inherited culture, which radically differentiated them from animals (Markus, 2011, p. 634). The nineteenth century, with its thought exacerbated by the industrial revolution and utilitarianism, transformed unlimited reason into a hidden object, eliminating the last vestiges of respect for nature, including animals (Moscovici, p. 158). This rationality underlies modern totalitarianism, which rationalizes and destroys all the ancient savoir faire, traditions, ways of life, and other vestiges of the past.

The books being analyzed were written between the years 1930 and 1945, which coincided with a time of intense ideological struggle, the desire for order, the irresistible rise of totalitarianism, the exacerbation of modernity, and the outbreak of the Second World War.

Both authors were masters of their texts, and both produced passionate works in which the dog was not only a powerful protagonist, but a personality of its own - a kind of primordial deity. It is in the regions where animals were exiled that they were personified, dethroning the machine that not only mechanized human beings but also threatened to destroy them by the ravings of science. Abandoning the definitions that established human beings as superior to animals, our authors sought to rescue an old lost brotherhood, making the dog our brother, friend, and our master.

\section{Literature: Animals and Social Communication}

Literature on dogs seems to begin in the earliest stages of writing and continues to this day. Different writers living in 
distant countries and environments have written about the dog, emphasizing different points of view. In many cases, authors have written about the dog allegorically and symbolically (Farina, 2014). Grandin, an American scientist, whose essays from her extensive field work extol the role of animals by referring to them as beings worthy of respect, claims that it is thanks to them that the species homo sapiens has triumphed in the face of $(2009$, p. 75).

Some studies in the field of communication maintain that animals do communicate and have a culture (Gross \& Vallely, 2013). The expansion of these studies runs parallel with the perception that human communication no longer holds central place in the process and that animals are also an audience (Plec, 2013, p. 5). Among the animals, dogs belong to a symbolic niche with close proximity to humans. According to Shukin (2009, p. 3), this ensures them a broad significance that includes fetishist functions in psychoanalytic theory. In the arts in general, there are numerous examples of symbolic and metaphorical use of the dog, establishing a poetic bridge between life and death (Nigianni, 2014, p. 99).

To illustrate this initial discussion, we highlight "The Tunnel," the fourth episode of the film Dreams (1990) by Akira Kurosawa (1910-1998), in which there is a dog that that enables communication between two worlds. The dog employs a persuasive rhetoric, convincing a man who stands on the threshold between life and death to decide for the former. The man is an officer of the Japanese Imperial Army, who, following the surrender of his country, is returning home. During the war, every soldier of the unit he had commanded had died. While approaching a desolate tunnel, the officer's way is blocked by an aggressive dog, much like Cerberus, the guardian of Hades, the afterlife or underworld in Hellenic mythology. Clad in warrior's attire (a rhetorical technique), the animal pushes the officer into the darkening tunnel. Like the dog described by Shukin, Kurosawa's dog is a spectral beast belonging to a paranormal time and space, one that does not seem to be either dead or alive, but who stops to stare at human beings. As Shukin points out, although animals have disappeared in modernity, effective communication between them and human beings has been kept alive in the movies (Shukin, 2009, p. 40).

This episode of Kurosawa's film presents the tunnel as a rite of passage, a transposition of boundaries, which brings us to the matter of liminality as described by both Segalen (2009) and Turner (1969). In the thought of both, though there are different nuances, rites are revealed as social requirements. The tunnel, this metaphor of the passage between life and death, is transposed by the official, who fulfills the basic requirement of performing a ritual - to be alive and to be aware of it. The officer is not a tribal individual but belongs, like his soldiers, to an industrial society. They wear uniforms and helmets and carry industrial weapons. The liminal force of the tunnel shows that the officer is a subject who accesses the liminality and emerges complete after ritually transposing the tunnel. In the case of the soldiers, this does not happen. They are dead but are unaware of their state, and this quality prevents them from accessing the liminality and leaving the transformed tunnel, that is, ascending from the status of living beings. For Segalen, the notion of the presence of these rites in the modern times of World War II reaffirms the idea of the presence of underground and marginal forces in the social life (2009, p. 36). The sergeant leading the unit emerges from the tunnel and reports that the soldiers, who had served under the officer's command during the war, now wish to return to their families. The officer, however, tells the men that they are dead, and, in a commanding voice, orders them to go away. Obeying, the phalanx moves away in the darkness until the sound of their marching boots becomes inaudible. At that moment, growling, the dog pushes the officer away from the tunnel. He is alive, and should appreciate this gift granted to him.

The medieval Iranian poet and author Ibn al-Marzubān wrote a remarkable work entitled The Book of the Superiority of Dogs over Many of Those Who Wear Clothes (1978) that seems to follow the Persian cosmology of Zoroastrianism, in which dogs are described as being close to humans (Farina, 2008, p. 191). In the work of Ibn al-Marzubān, dogs are shown to be completely trustworthy, unblemished beings, unlike humans, who are fickle, selfish, and cowardly (al-Marzubān, 1978, p. 50). In the translation by Hofer, Ibn al-Marzubān thus expressed himself in a way that recalls Malaparte. "People are pigs these days. If you see a dog, hold on to it, for it is much better than the people of our time" (Ibn al-Marzubān, 1978, p. 78).

The Portuguese communicologist Sousa, in defining social communication, does not exclude the possibility of animals communicating with humans; for example, when a dog wags his tail (2004, p. 13). Rogers and Kaplan point out that communication is a wide expression and is defined as polysemic. With respect to a human as an individual, communication emphasizes its intentional nature directed to another individual (Rogers \& Kaplan, 1998, p. 2). The same authors, in a work titled Not Only Roars and Rituals: Communication in Animals, reiterate their claim of communication among animals and between animals and humans (Rogers \& Kaplan, 1998, p. 25).

Loyalty between human beings and the beasts leads the first to establish a dialogue that seems to come from a partnership formed in a mythical place situated at the dawn of history. On this lost communication and coexistence, Schnapp-Gourbeillon provides an explanatory key, saying that

Men and animals have been dating for a long time; They have, so to speak, enlarged together. . . In each of the collective experiences of humankind, as there is no society without imagination, the animal is itself and its double: 
doubled social, cultural, human (1981, p. 10).

\section{The Dog in Literature}

In some of the most important works of world literature, such as Homer's Odyssey, the duality of dog and human is exalted as a mixed relationship, full of affection and gratitude. The archetypical champion of miscegenation, the hero Ulysses/Odysseus has an elderly, blind dog named Argos (Laplantine \& Nouss, 1997, p. 388). Homer grants him the ability to recognize its owner and friend, who is returning to the palace incognito, disguised as a swineherd. Argos triumphs in the very task at which Odysseus' wife Penelope, his son Telemachus, and his devoted servants, such as Eurycleia, have failed—recognizing his owner.

This meeting represents the wonderfully common place where dogs and humans communicate because, as Lippit writes, animals are associated with fables and myths produced by human beings. Because animals are not provided with language, they need to employ noises and gestures as a form of mediation or allegory to be understood by humans (2000, p. 7).

Because some cultures regarded dogs as impure, they left scarce vestiges of them. However Greco-Roman antiquity bequeathed to us an enormous number of artistic objects and texts portraying dogs (Johns, 2008, p.6). Romans such as Columella (4 BCE-70 CE) wrote about the dog, even suggesting that shepherds used white dogs that were more visible than the wild beasts (Columella, 1968, p. 8). The dog's relationship with humans surpasses the gates of death, going beyond the final outcome, as denoted by a report dating from the last days of the Roman Republic (509-27 BCE), when the civil wars ravaged Rome. An event shook the townspeople's readers, and they were confronted with the hidden rules of animal reason that pointed to a faithfulness that even death could not break. This was privileged as one of the rare news accounts in the first known journal, the Actas, in whose form they arrive to us today, though originally, they were called the Acta urbana, which Bailey translated as "The City Gazette" (Moatti, 1997, p. 382). The editing of these first known examples of written news media is attributed to Gaius Julius Caesar. There was a literate audience in the shape of a reading public, who followed the reports through this Roman newspaper.

During the political turmoil in the city, a man was thrown into the Tiber River and drowned. While carried by the flow, the man's lifeless body was followed by his distressed dog. The animal, sensing the fatal outcome, rushed into the water and swam to the body of its owner. However, the dog was carried away, and the two bodies disappeared. The public followed the account of the dog's gesture, which went against reason, politics, or parties, with astonishment. This loyalty at any cost, this inextricable relationship in a time of merciless complaints, moved the ancient Romans.

The origins of the dog-human relationship are enveloped in mythical narratives, explains Malinowski, for whom myth "far from being an idle mental pursuit . . . is a vital ingredient of practical relation to the environment, . . on the contrary, it is a living reality" (1984, p. 147). In turn, the French philosopher Roland Barthes (1915-1980) regarded the myth to be alive, and his interpretation was confirmed by Burkhert, who considered it an applied narrative (Burkhert, 1991, p. 18). Thus, the applied narrative of speech recalls the practices of a remote time, when humans and animals attended to and communicated with each other, before the historical break that determined the domain of the human. The human turned the animal into a dependent being, and most recently, the animal has become a commodity. Or, as Beston wrote:

In a world older and more complete than ours, they move, finished and complete, gifted with extensions of the senses we have lost or never attained, living by voices we shall never hear. They are not brethren; they are not underlings; they are other nations, caught with ourselves, in the net of life and time. (as cited in Waldau \& Patton, 2006, p. 27)

However, if we would deepen our world experiences in contact with animals, certainly we would attain a more balanced humanity (Steiner, 2010, p. 1). This is what is suggested by the analysis of the human-animal relationship in England in the nineteenth century by Mangum. Her work, titled "Dog Years, Human Fears," analyzes the literature and painting of Victorian England, showing the touching qualities permeating the relationship of animals and humans. Both share feelings and workspaces that may be translated as intense companionship intercepted by the unique chronological unfolding governing their existence. As the dog is provided with a shorter life cycle than the human, it reaches advanced age earlier than humans. It is as if nature were preparing the animal to reach maturity without learning to speak and, in his path, to follow part of its owner's life (Mangum, 2002, pp. 38-39).

As dogs precede us by anticipating our time, so their coexistence with us prepares us for old age, suffering, and death. The animal is associated with protecting people before the mystery of existence, for the dog, sensing the inevitability of death, resigns itself to it, thus teaching us how to function in this crucial transition.

In the past, the shedding of the blood of animals was a means of communication with the sacred. Their ritual sacrifice made them superior, because they reached the divinity and we did not. In the episode of the sacrifice of Isaac, his being 
replaced by the lamb seems to show the importance of the animal in the context of Judeo-Christian cosmogony. As pointed out by Steiner (2010, p. 123), the attention and compassion that connect us to animals establishes the reinforcement for an improvement in our standing before God. The compassion shown toward the animals is somehow allegorical of our condition.

Levi and Malaparte, when writing about dogs, remembered what Moscovici called the genetic composition linked to anatomical and physiological organization. For the French philosopher, "Nature is double, split: original by its foundation, artificial by circumstances. The historical development of the individual and of society bears witness to the extirpation of the primitive framework and the tyranny of matter" (Moscovici, 1994, p. 18).

Genetic organization in a pure state and with little or poor manifestation of the logos (human rationality) is associated with children and wildlife. Both are animated by sexual and aggressive anarchic impulses, without looking to the interests of others, the community, or the law. The mission of law as rational human production is to curb our animal instincts, for at each stage of human development, societies exclude the natural for the benefit of cultural aspects. However, during the time of totalitarianism, when Levi and Malaparte wrote, the excess of modern rationality, as the Spanish painter Goya (1746-1828) pointed out, produced monsters.

\section{Dogs and Modernism: Communication and Anthropocentrism}

In their works, Levi and Malaparte refer to the canine ability to communicate with human beings as the result of an original animality shared by both in a lost time. The conviction that underlies their writings is rooted in the ancient imagination, whose representations are always reinvented (Lavaud, 1999, p. 220).

In Malaparte's work, the dog is associated with the human being, causing him to better understand his humanity. In Levi's writings, the dog is independent in its own way, complementing the lives of human beings. In both writers' literature, dogs occupied leading roles to teach us the virtues that modernity has destroyed. We can think of "dog" from the ambiguous perspective of the pharmakon of Plato and in accordance with Jacques Derrida, as a concept understood to have a chain of meanings. The word was of pivotal meaning (Derrida, 1972, p. 120). Pharmakon has ambiguous qualities and capabilities in its essence. It can be a beneficial remedy that curbs a disease if supplied to the patient in a certain quantity. In excess, however, it can cause death - although it can also be associated with a sacrifice. For Plato, no remedy was harmless; it continued to be a poisonous remedy (Plato, 1952, p. 157).

For some philosophers and thinkers, fascism unleashed a latent anarchic animality. The rise and support of Fascist, Hitlerist and Stalinist dictatorships, which continued for so long in power, was due to the absolute support of the masses. These rulers bragged about past crimes and planned future crimes. For totalitarian systems, evil was mightily attractive. Manifesting contempt for moral standards, it was considered the most powerful psychological factor in politics from the 1920s to the 1940s (Arendt, 1973, p. 306). No wonder sensitive writers such as Levi and Malaparte experienced a certain weariness for humankind, and no wonder the dog became a deep source of inspiration and moral teaching for both.

As described in the works of Arendt (1973) and Poulantzas (1972), the totalitarian systems had laboriously, systematically, and consistently constructed processes of inclusion and exclusion in their gears. Those individuals capable of thinking and criticizing or belonging to groups defined as outside the totalitarian system were doomed. In the works of Arendt and Poulantzas, details appear that are capable of dissolving the rational process to the point of madness, typical of these totalitarian systems. In the case of Nazism and Bolshevism, the practices of secret societies seem to be reflected in the ritualistic activities that led individuals to cross "tunnels" to see themselves in a new life. The marches on Piazza Venezia in Rome or the celebrations of Nuremberg provided images or organizational tricks intended to create a "shared existence by means of a secret ritual capable of consolidating identity bonds "with the members of our own blood and with no one else" (Arendt, p. 427). The totalitarians imitated the secret societies, but in their practice, they suppressed the secret. The world lost its nuance, and vulgarity became the norm.

As Gat demonstrated, both Nazi Germany and the USSR developed policies of total extermination, treating entire populations as cattle to be mass exterminated (2015, p. 562). Both used strategies marked by cynicism and falsehoods, exalting the supreme leaders as infallible (Arendt, 1973, p. 433).

Malaparte and Levi seem to debate a symbolic re-ranking of the universe and pose a spiritual and sensorial question: What cognitive and sensitivity bond has been lost for us, and whose language has become foreign to us? We pet the dog and give him food, shelter, and a name; would that have been enough in the distant past, when we were like family? These humanized animals are seen as our doubles, and they become the image of individuals, families, and groups.

In this regard, Waldau and Patton write about a unique archaeological find displayed in the Museum of Israel in Jerusalem. It is a prehistoric burial where the remains of a human and of a dog are lying across from each other (Waldau \& Patton, 2006, p. 27). The relationship pointed to by these remains seems to show full confidence and mutual affection between dog and human, who share their dwelling for eternity. This gesture reminds us of the observation of French writer France 
that as long as one could not love a pet, part of one's soul would remain unknown (as cited in Waldau \& Patton, 2006, p. 27). Patton also refers to a mixed feeling of shock and joy that takes over all humans whenever they see a large gathering of animals. This aggregation reminds us of the strength that the land possesses, reconnecting us to an ancestral, lost world. In the past, animals were of a seemingly infinite number, while we human beings were few. Facing the prospect of being outnumbered, we humans have seen to it that animals have become more and more scarce, even at risk of extinction. A technical staff member of "biopower" should decide, by whatever criteria, the species that should be spared and the ones that should die (Patton, 2006, p. 28).

\section{Carlo Levi and His Dog Barone}

Carlo Levi (1902-1975) was one of the most important peninsular writers of the twentieth century. Born in Turin, he graduated from medical school; he was also a writer and painter (Donato \& Amaro, 2005, p. 37). His free spirit soon led him toward anti-fascist activism. After his arrest, a police report described him as "an intelligent and evasive individual who knows how to skillfully mask his actions." Following his arrest and cross-examination, Levi was locked up for three years with other convicted felons and conspirators (Colangelo, 2008, pp. 15-16). Attempting to help him, several influential artists, including Signac, Derain, Léger, and Chagall, wrote Mussolini a manifesto demanding his freedom.

Being exiled would be a devastating experience for the average person. However, as Malaparte explained, the sensitive person escapes captivity through his intelligence. For Levi, the Lucania exile represented an encounter with a both new and ancient universe, revealed through literature. In 1945, he published his memoirs in the book Cristo si e fermato a Eboli (Christ Stopped in Eboli), which soon became a public and critical success. This novel is an iconic text, indicating that it is the work of a writer who happens to be a painter as well (Levi, 2004, p. 37). It takes us through "a world hidden by pain and tradition" in a place called Lucania, a rural region of southern Italy, where a desert landscape increases the sense of isolation in time and space. Just as totalitarian systems both excluded and included, peasants in the Lucanian region saw history and religion as systems of exclusion-inclusion. The Lucanian peasants referred to themselves as excluded or forgotten by history, by various societies and states, and by Christianity itself. It refers to a land "forgotten by all, ignored by the great conquerors of the past." The inhabitants say: Neither the Greeks, nor the Romans, nor the Normans, nor the Aragonese, not even Christ could reach it; they stopped in Eboli and did not enter Lucania where these poor people lived" (Levi, 2010, p. 8).

When the inhabitants lamented to see the writer exiled and punished as one who was equal to them, they identified themselves by resorting to another essential tropism: duplication. This bipartite character, this existential duplicity extends to their names. They have two names: one baptismal and official; the other, real and the bearer of magical abilities before nature. Or, according to Cassirer, the name of the ontological root of being is the hidden meaning of life (1953, $\mathrm{p}$. 52).

In her scholarly essay, Galvano elucidates the name issue, so that Lucania is the name that has "a mythical foundation, or, as the Bible refers to it, the adamic origin" (2004, p. 170). Far from being just an empty controversy, it is about adjusting the word to the sense given. As Cassirer explains, "We find a relation of identity of complete congruence between image and object, between the name and the "thing"' (1946, p. 58).

Levi's exile, which lasted nearly five years, began in the remote village of Grassano, "whose aridity, isolation, and solitude was reminiscent of one place of martyrdom, Jerusalem. The vigilance of the local Fascist authorities, upset with some visitors who sought the famous troublesome exile, transferred him, citing "security reasons," to another village called Aliano (Colangelo, 2008, pp. 21-22).

This was an agglomeration far from the rail network. In his narrative, Levi renamed it Gagliano. If Grassano was lively because of its proximity to the provincial road and trains, Gagliano, on the contrary, was very distant and a complete wilderness, as it still is today. The village boasted both an animal and a duplicate shape: "It went down and coiled like a worm around a single street, between two steep cliffs" (Colangelo, 2008, p. 23).

\subsection{Myth, Homeland and Animal Land}

The Italian painter Sacerdoti (1944-2013) believed that the intense animal presence in our imaginations reflects the importance attached to them in our daily lives. Lucania, Sicily, and Sardinia, where Levi travelled, were places with a high animal density. When he later travelled through cities populated by cars, such as Berlin, Moscow, and Rome, he continued to see myriads of animals, as if he were still in southern Italy (2004, p. 99). Levi's writing follows the principle that di Donato calls granting full emphasis of object to the "desolate and squalid aspects of humanity stripped of everything, even the word" $(2005$, p. 12).

In Levi's writing, the senses are present. He registers the smells and the sounds that also compose the landscape, or topoi. The silence of the clay hills, for example, produces a sound. If, in Grassano, he was awakened by the bells of the flocks, in impoverished Gagliano, it was by the sound of the hooves of the donkeys and goats, which the poor peasants led away 
early for a journey of three to four hours to "reach their fields in the unhealthy ravines of Agri and Sauro." When forests were cut down, the clay ground with no vegetation cover was worn down under the impact of heavy rains and walkers' feet. Landslides engulfed churches, houses, and streets. No action was taken to avoid disaster; "But it's the same thing every winter, which overtakes this village and every other village of the province. There are no trees and no rocks, and clay breaks up and slides down like a torrent dragging everything in its way" (Levi, 2010, p. 39).

When he was contemplating the village, Levi realized that the place was metamorphosing, duplicating itself:

I did not see Gagliano entirely. It was coiled like a long snake hidden among rocks; but its yellowing red roofs were glimpsed through the grey tops of the olive trees shaken by the wind, like living things, contrasting with the current immobility; behind this colorful foreground, a large extension of bare clay seemed to curl in the warm air suspended from the sky, and above their monotonous witness, the moving shadows of the summer clouds passed. (Levi, 2010, p. 51)

The village of Gagliano was burning hot during the summer and freezing cold in the winter, as was the capital of inhuman power. In this land of mysteries, the animals had more occult powers than the humans, and Levi seemed to believe in these powers:

In the abandoned village, the charm of the animal kingdom seemed to widen. . . . The roosters crowed; but it was an afternoon song and without the petulance of the morning greeting, but one of vast, infinite sadness extending from the enormous desolation. The black flights of ravens filled the sky, and above, the orbits of hawks were drawn. I felt their round and still eyes following me. Once I had entered the realm and contacted its inhabitants, new keys to the mystery kingdom, this mythical universe, were revealed. . . The unseen presence of invisible animals floated through the air. Suddenly, behind a house, emerged, with a leap of its bowed legs, the queen of those places - a goat, which fixed upon me its yellow and indecipherable eyes. (Levi, 2010, p. 58)

Among all the animals, the goat was revealed to have greater powers - the key to penetrating hidden realms — which, it seems, it could unveil.

The peasants say that the goat is an evil animal. All animals are diabolical, but the goat is worse than any other. This does not mean that it is bad or has anything to do with the Christian devil, although the devil does sometimes take its shape to make his appearance ... more than any other revelation, for under its animal appearance, it hides something that is pure power. (Levi, 2010, p. 174)

Another place for mediation, and also a key, was the cemetery of Gagliano, where the dead and living communicated, and which was for Levi "the upper limit of the space I have been granted. From above, the outlook was wider than any other point, and less desolate" (Levi, 2010, p. 41). In this land of elves, souls, and apparitions, the cemetery had a special significance as a magic door, not only for communication with the underworld, but for understanding himself: "I was approaching the cemetery, accompanied by these looks neither human nor divine, surrounded by mysterious powers." Amid the bleak summer landscape, it was "the only closed, cool, and lonely space of the village. . . It was also the least sad place. In this Elysium, where the blinding whiteness of the clay was hidden by the wall, I was able to feel a different peace. The cypress trees swayed in the wind, and among the graves grew clumps of roses. I was a stranger in a land without flowers" (Levi, 2010, p. 42). Levi slipped down into an open grave in the cemetery to enjoy the evening freshness, read, and sleep "deep down," where the sun does not burn within. Looking up, he did not "see more than a clear rectangle of sky and an occasional wandering cloud. No sound reached my ears." From time to time, Levi's remarkable dog, Barone (Italian for "baron"), went down the stairs and kept him company. His origin was shrouded by mystery. The fully-grown dog had been found by railroad workers who, given the solemn aspect of the animal, entrusted him to Levi. The dog's majestic size and bouncy pace, which fluttered his long, silky fur, reminded Levi of the noble animals that populated the heraldry of medieval shields. The peasants, seduced by Barone's gallantry and grace, supposed him to be the guardian of the meanings in the imaginary borderlands. Barone was half dog, half lion; he was a cheerful dog, the curious guardian of the mysteries of his harsh, wild, and beautiful region.

In this obscure little town of Lucan, the gravedigger also played the role of village herald, circulating along the main street, "blowing a trumpet and beating a drum hanging around his neck as he announced the news of the day in an inhuman voice." In addition to the information transmitted to the living, it was he who led "the dead to the cemetery, dug their tombs, and buried them." They had respect for him, almost fear. The old man had a mysterious power; he had relations with underground forces, knew the spirits, dominated the animals. And he had been a wolf charmer in the land of the wolves that had given Lucania its name. "At will, he could make the wolves come down to the village or depart from it; those wild animals could not resist him. They had to obey him." The powers of this old man were multiple, but did not affect women. "His charm was exercised over the natural elements, even over the spirits that wandered in space." People told of his feats as a youth, when he had gone out with others to mow a field of wheat all day long. At the end of the day, when the others were weary, "dirty with sweat and dust, with their backs sore with fatigue, and their tanned 
forehead burned by the sun, the wolf charmer was fresh and rested, as if it were still morning."

\subsection{In the Land of Wolves, a Dog Rules. Barone: Half Dog, Half Lion}

The city of Eboli is a place of mediation where the visitor leaves the modern Christian world and enters Lucania, a land of old habits, though these are not historical. It is inhabited by a population of invisible beings, earth spirits, and the souls of the dead, by animals, angels, and demons. It is a "different world, hidden in pain and in tradition, ignored by history and by the eternally passive state" (Levi, 2010, p. 9). For Levi, it was as if he were walking in an area without history as the region had kept its original name of Lucania, "land of wolves" (i.e., primeval dogs). It was considered apart from Rome, from the Fascist hierarchies, from civilization, and ultimately, from history itself. The area is desolate and dotted with villages and small towns, like islands in an earthly, rugged, and harsh sea; scorching in summer, brutal in winter. The life of this peasant civilization is expressed in appropriate and non-transferable codes, where the imaginary becomes the explanation for the routine, tempered by the brutish local authorities.

In his confinement, Levi would get to know the local authorities (most of them Fascists), some incompetent and jealous doctors, a hated elderly priest, and pawns, ranging from gentle to obtuse men. There were other exiled people, such as the Milanese, the oil negotiator, the communist bricklayer, and the young and gorgeous Sicilian brunette, whose guardian, the local commander of the Carabinieri, was burning with desire for the woman. Levi refers to Matera's judiciary policeman with courtesy because he shows civil and human characteristics, typical traces of a culture not yet dominated by machines and fascist enthusiasm. When he arrives at the place where he will stay while exiled, Levi finds he has at his disposal a beautiful "witch," as he calls the woman named Julia, whose stunning body is crowned by a small head whose shape reminds him of a viper. Julia, with her body lusting for sex, and the festive dog, Barone, were his only friends during that exile, which only ceased when the fascist troops conquered Abyssinia (Colangelo, 2008, p. 34).

The eccentric animal could not tolerate the sound of the bells of the sacristans, causing Levi to suspect that maybe he was hiding a diabolical creature (Miccinese, 1979, p. 38). Unlike the perishing scapegoat that bears all of the community's sins, Barone presents himself as a blameless being, full of positive moral disposition in a world dominated by dictatorship. "A cheerful, free, and wild being," he is the natural element that mitigates the bestiality, the terrible human greed, and the small and sordid townspeople in quiet Gagliano.

The dog in Levi's writing appears as the hinge between the cosmic forces and death. The peasants, closer to this matrix than the civilized and rational citizens, soon decode the duplicate sign of divinity in the animal:

[This] dual nature that always engenders an obscure attraction that implies respect concerning the participation of village deities. All of them recognized something sacred in my dog. They did not look at him as a normal dog; he was an extraordinary being, different from all dogs and worthy of being particularly worshiped. (Levi, 2011, p. 25)

Barone was a holy being and doubled as Levi himself for his Fascist opponents: "In their fear of the sacred, they also found in me a double nature: half baron, half lion" (Levi, 2011, p. 25). In his writing, Levi describes the peasant word "Galvagno" as "magical and poetic, participating in double meaning and ambiguity, contrary to the univocal direction of reason" (2004, p. 173).

\section{An Animal at the Crossroads: Malaparte Between Modernity and Totalitarianism}

The work of Curzio Malaparte, an intellectual marked by different cultural boundaries, is constructed from a fabulous and mythical fabric. In his multifaceted writing, among which we list Technique du coup d'état (1931), Fughe in Prigione (1936), Kaputt (1944), and La Pelle (1949), we find several animals among the narratives. However, the most important protagonist was his own dog, Febo, or Moondog, as he called him. Febo was the old dog of ancient Greek myths, the kind of dog that has the power to drive death away. Malaparte realized the modern ambiguity regarding animals: they can either kill them en masse or in a modern, industrial way. Their prodigious numbers turn them into beings deprived of any rights to life. The modern utilitarian "massification," applied at slaughterhouses and farms, was the same technique, now employed to eliminate massive herds of animals, that had already been used to exterminate human herds. Therefore, the Holocaust was part of the modern design and not exclusive to Nazism/Fascism. Since the sixteenth century, this design had been employed with this modern arsenal, from the Indian and African genocides to the famines in Ireland and India of the nineteenth century. Polanyi suggests that in the early twentieth century, there was a dramatic change of course in rational thinking, which led to unthinkable ends with the emergence of totalitarianism and rising crowds (2001, p. 244).

For Novek, depersonalized animal concentrations are the best metaphor for the crowds of faceless people and this is what happens to societies of organized crowds that are herded like flocks, as in Bolshevik Russia and Nazi Germany (Novek, 2012, p. 140). Perhaps the political novel Animal Farm (1946), by George Orwell, best summarizes this modern and impersonal metaphorical contribution of mediating the flocks, the disciplined crowds (Orwell, 1946, p. 
275).

Bauman defends the idea that human society is different from a bunch of animals, because it is based on compassion and care for others, a quality found only in humans. Society ensures and preserves those who are diminished by disabilities. The contemporary concern is all there: to take this compassion and concern to a "planetary scale" (Bauman, 2005, p. 90). This feeling of human solidarity has been present since the dawn of society.

A fossilized human skeleton was discovered in a prehistoric burial. The skeleton was that of an individual whose leg had been broken when he was a boy, and yet he had not died until the age of thirty. The anthropologist's conclusion was simple: he must have been part of a human society, because something like that would not happen in a group of animals, where a broken leg would put an end to its life, for the creature would have no conditions to sustain itself (Bauman, 2005, p. 90).

\subsection{Malaparte: From Kurt to Curzio}

The very existence of Curzio Malaparte is connected to European culture, in that around 1870, Italy and Germany were both unified, which permanently changed the European balance (Joll, 1990). Italy proved to be divided between a rich "European" north, which was cosmopolitan and industrial, and an agrarian south, which was under pressure from large landowners. There were still gaps left by a neglectful state in the consolidation of citizenship, and the mafia system was meddling in the gaps with ease, supported by rural landowners and the urban industrial bourgeoisie (Joll, 1990, pp. 8-9). Banditry was raging in the Mezzogiorno, and popular outbursts amplified the tensions arising from poverty. The vigorous industrialization in the north and the lack of capital in the poor and agrarian south seemed to reflect the contradictions of European modernization (Bayly, 2004, p. 283).

After the First World War, liberalism in Italy proved unable to provide an adequate response to the serious problems resulting from modernization and the general capitalism crisis. In the clashes between right and left, fascism emerged as a new force from the ruins and feeling of disillusionment after the First World War. In the 1920s, fascism had been linked with big business capital, which had consolidated and flattened the salary gain (Poulantzas, 1970, p. 161). Although Mussolini considered the "urban framework" crucial to the problem of power, he realized the importance of the south and the agricultural character. In 1922, the new context and the National Fascist Party were articulated (Poulantzas, 1972, p. 164).

As Latour emphasizes, modernity is multifaceted, full of contradictory meanings, and asymmetrical in its cognitive-temporal division between an accelerated and reified temporality — so modern — and a slower one, subject to the action of the archaic tradition (2000, p. 14). Despite the inequalities, Italian literature experienced a large growth during the late nineteenth and twentieth centuries (Hobsbawm, 1988, p. 129).

The big push for modernization from the most advanced northern circles culminated in the futurism experiences, even though the vanguards should be viewed with a certain suspicion due to their anecdotal character. For Hobsbawm, "perhaps nothing better illustrates the identity crises faced by the bourgeois society in this period and the arts in the years 1870 to 1914" (Hosbawm, 1988, p. 308).

Modernity is present in Malaparte's journalistic literature, not as chronicles, but as autodiegesis. He was an Italian correspondent in Nazi Germany, occupied Europe, and the Finnish front until the armistice in 1944, when Italy joined the Allies, after which Malaparte covered the actions of American, French, and Canadian troops. All his books are path works, such as his provocative The Volga Rises in Europe (1943). It is a compilation of newspaper articles covering the Second World War on the Eastern Front. In them, Malaparte demonstrates a descriptive obsession about how industrial modernity is represented and affects the contenders.

Malaparte followed the great German advance in the steppes of the Soviet Union and embarked on an armored column made up of "steel horses." Along the way, amid panzers and Jägers, he remembered the novel by Leonov, a Soviet author whose work depicted a hypothetical war carried out by machines. He asked the German lieutenant who accompanied him if he had read Armored Train No 1469. He answered negatively, and they both ended up talking about the war and modern equipment. The German officer confessed that "from the social viewpoint, machines are very interesting and very dangerous characters" (Malaparte, 2002, pp. 76-77).

During the battles he witnessed at the Russian front, the writer experienced the disturbing and unsettling feeling that the machines in the armored column were becoming alive, "a miracle, yet it is only the fruit of a technique that has been brought to perfection, the fruit of a scientific method of making war. ... An armoured column is a precision instrument par excellence" (Malaparte, 2002, p. 58). Referring to the opponent of the Germans, the fearsome and fierce Soviet fighter, he did not describe him as a human being, but as a hybrid: half machine and half human. He was a true product of an operation that engendered a kind of being between the natural and the industrial that, for Malaparte, had ceased to be human, although it was not yet a machine - in fact, it was a new being: "The stakhanovites of the Stalin army, the udarniks, 
the authentic creatures of the Pyatiletkas, the products of Lenin's famous formula, 'soviet + electrification = bolshevism."' Observing closely some Soviet soldier corpses, he paused carefully to consider their "faces, their narrow, hard, obstinate faces. They are all the same. Mass-produced. They typify a new race, a tough race, the corpses of workers killed in an industrial accident" (Malaparte, 2002, p. 61).

The Red Army, which was battling against the Germans, was for him, "the supreme creation of Soviet Russia." Everything in it, from its weapons to the spirit, was the result of twenty years devoted to the training of skillful craftsmen (Malaparte, 2002, p. 40). In the Alexandrovka village, Malaparte, finding himself in front of a column of Romanian soldiers, offered to lead a prisoner who seemed to have embarrassed them. He was a Soviet Tartar, who should have been handed over to the German troops nearby. In the middle of the night, he had hidden in an abandoned house where a dead, decomposing mare was lying by the door. While the Romanian soldier who was guarding the prisoner slept, Malaparte offered a cigarette to the Soviet soldier, who was tied up (Malaparte, 2002, pp. 40-41). On that occasion, he noted "the hands of a young Tartar recruit, who was converted to a tank driver mechanic: ennobled by the ancient, millenary contact with the silky skin, the mane, the hocks, the muscles of the horse." Here, tradition is completed by modernity because the machine culture is added to the first, resulting in a dialectical dimension that produces a half-bred human being: half man-half machine; half man-half animal.

\subsection{Malaparte Is Not a Dog Like Me}

The ambiguous reputation surrounding Malaparte's personality oscillates between those who discredit him and those who consider him a chameleonic author (Martellini, 1977, p. 139). Despite the fact that some accuse him of being an egoist, Hope sees in him one of those rare authors who could use their writings to consolidate their self-image (Hope, 2006, p. 180). As an experienced author, Malaparte's enormous inventive capacity produced the narrative of memory, stubbornly resisting writing a chronicle (Martellini, 1996, pp. 116-120). In Malaparte's work, the critique of modern totalitarianism shows that natural selection led to mass extermination and the pursuit of living space led to the extermination of people. The Nazi totalitarian policy had put in place an achievement project based entirely on the Nazi knowledge of modern economy and its labor system (Kaiser, 2000, p. 380), wherein the use of slave labor secured an extraordinary increment in war production (Kaiser, 2000, p. 281).

When Malaparte underwent successive arrests under Italian Fascism, he experienced a solidarity with intellectuals from all over Europe, which increased his sense of being a victim of a powerful machine (Hope, 2006, p. 66). Books like Donna come me, and Un santo come me, seem, in the opinion of Hope, to deny the reader access to the narrator, whose presence can only be sensed as the reading progresses (Hope, 2006, p. 67). Malaparte was on the front line and took part in the March on Rome in 1922. In the beginnings of the Fascism Régime, he was a squadristi (Fascist assault troop), having created a magazine to expose the Fascist ideals (Pugliese, 2001, p. 105). After breaking with Mussolini, his sour irony earned him the hatred of the regime allies, but his comments continued until Italy's surrender in 1943 and the consequent alignment with Western Allies.

\subsection{Malaparte and Febo, the Moondog}

In Malaparte's work, the dog displays a behavior that people should imitate. Febo is a particular animal model, who is presented as being on a much higher plane than humankind. According to Malaparte:

I have never liked a woman, a brother, or a friend as much as I liked Febo. He was like me except he was dog. . . . He was a noble being, the noblest creature I met in my life. He belonged to that rare and delicate greyhound family, coming from Asia along with the first Ionic migrations, and whom the shepherds of Lipari used to call cerneghi. (2006, p. 182)

These were dogs that Greek sculptors had carved in bas-reliefs on tombstones. "They frighten death away," said the shepherds from Lipari (Malaparte, 2006, p. 182).

This moondog faithfully followed Malaparte when he was sent into exile by the Fascist regime. He was the one who followed him and waited. During the winter of 1940, Malaparte took refuge in Pisa to escape the war. He had with him this dog of his, the one he had found more dead than alive on the beach of Marina Corta on Lipari Island. Since then, on the island where he had been exiled, the dog had become his faithful friend, the one who had neither abandoned nor denied him (Malaparte, 2006, p. 38). For the expatriate, the dog's presence on the islands where they lived in solitary exiled homes, was "a wonderful presence," capable of restoring the writer's perception of the full extent of the expression of brotherhood. "He was not only my brother, he was my judge . . . the keeper of my dignity, and at the same time, he was, I will say, using ancient Greek, my dorufórema (Greek word for bodyguard)" (Malaparte, 2006, p. 184).When he was led handcuffed through Naples, thirsty, hungry and verbally abused, the writer turned backwards "from time to time to see if Febo was following me, and I saw him brush against the walls, tail between his legs, along the streets of Naples, from Immacolatella to Molo Beverello, with this wonderful sadness in his pale eyes" (Malaparte, 
2006,184).

Handcuffed between two carabinieri, Malaparte was conducted under the scorching July sun along the pavement of Via Partenope, when he saw two Italian ladies approach. One of them was the daughter of the famous Benedetto Croce, and the other was Minnie Casella. Both "greeted me with the maternal kindness of Italian ladies" and sought to intercede with the law enforcement officials. Malaparte replied that he did not need anything. He asked, however, that they give his dog water to drink. They turned to Febo, who "kept staring at Mrs. Croce with painful intensity. It was the first time that he had stared at human kindness" (Malaparte, 2006, p. 47). In Luca, Malaparte was imprisoned for months, but when he was released, "Febo was waiting for me at the jail door, thin and covered in mud."

After being arrested again, Malaparte was released in Rome in such embarrassing conditions that it would have been better to have remained detained. Because of this, the dog was "sad; he looked humiliated by the spectacle of my freedom. He knew that freedom is not a human act, and that men cannot, and may not know, how to be free, and that freedom, in Italy and in Europe weighs as much as slavery" (Malaparte, 2006, p. 48).

In Pisa, Febo disappeared from the city streets. Malaparte, fearful for his fate, searched for him everywhere. When he managed to locate him, his worst fears were confirmed. The dog lay in a bed at the university veterinary clinic, transformed into a guinea pig along with the other dogs. Among the rows of dogs martyred by veterinary experiences was Febo. He was lying on his back; his belly was open. "He was staring at me and his eyes were full of tears. He showed a marvelous expression in his eyes. The doctor applied a lethal injection to the dog: He would fall asleep forever, he assured me." When Malaparte inquired of him because none of the dogs barked or cried, the doctor explained: "Before operating on them, they cut their vocal cords" (Malaparte, 1972, p. 188).

During the war on the Russian front, the Nazi troops hanged the unfortunate dogs alongside their Jewish owners, dressed in their heavy coats. "'Ho, the Jewish dogs, die jüdische Hünde!' said the German soldiers when passing by the hanged men and their animals" (Malaparte, 1972, p. 210). The dogs of this sad Europe were so loyal to their owners and fought in the war without receiving medals or merit citations. Malaparte points out that in the Russian steppes the mechanized Nazis fought with dogs that had been set against them by their Soviet antagonists. Malaparte witnessed this Dantesque clash between animals raised by men and the machines manufactured by them.

Desperate because of the ruthlessness of the Nazi advance, the Soviet fighters followed the doctrine of the Russian scientist Pavlov. They trained thousands of dogs to receive food beneath the carcass of a tank. Therefore, the hungry animals were released right in front of the German tanks and went running up to them to eat. They carried backpacks filled with explosives and were supposed to sneak beneath the armor; when the booster antenna touched the tank's belly, the backpack would explode.

The powerful German armored column was progressing when it was targeted by a pack of "Soviet" dogs. In the vehicles, the soldiers were frightened, "Die Hünde, die Hünde!" "The dogs, the dogs!" they shouted, as they heard the joyful barking of the dogs that ran from neighboring forests to eat beneath their tanks.

Watching their hosts, Malaparte "saw the white spot of fear born deep in the dull eyes of the German officers and soldiers." And, when Germans are afraid, he wrote, "the Germans become bad; and I regret being a Christian, I was embarrassed to be a Christian," he said. The running Soviet dogs, as if pursuing a pack of foxes, reached the column whose "Panzers were running in zigzag, firing furiously." Soon, Malaparte heard "the dull roar of an explosion, then another, and another. Five or six panzers went through the air, the steel plates sparkling between high dirty jets." The commander, General Schubert, turned to Malaparte, "ran a hand over his face and, looking at me, said, in a voice already dead: "Ah, why, why? The dogs too!” (Malaparte, 1966, p. 217).

\section{Conclusion}

In the works of Levi and Malaparte analyzed above, the dog is a major component; it is the element that enables a mediation between reason and imagination. The dog also holds a position in the connection between life and death, or rather, in the fullness of existence. The dog precedes the human being and waits for him in both life and in death. Reason points to half of existence; death is the other half, though strongly denied by the action of modernity. The death of the dog precedes the death of the human being; in this way, the idea of death can be softened for the modern person. The dog is our protector and the guardian of this world's secrets. He knows both worlds and precedes us in order to lead us to the green pastures of the Christian heaven, to Elysium, to the shadows of Hades, and — who knows? — to Valhalla.

Thus, establishing the bridge between the human being and his own lost ancient half, the dog prepares us for our inevitable death. Malaparte operates, in his writing, a total surrender to the animal. The dog, like us, expresses and reveals a complete brotherhood. That is, enhanced by the impression that the animal possesses an ancestral precedence, it is able to guide and to teach the human, so to speak, how to be a dog. For Levi, the dog is a lord, an independent partner, regardless of whether the human follows him or not. 
As Lippit has written, dogs are animals that do not die. However, just as the prehistoric burial in Jerusalem revealed an old friendship, and the Roman dog plunged to its death with its owner in the Tiber River, Malaparte is sure that the extension of this relationship continues even after death. At the end of his work, Cane come me, he wrote his epitaph:

But I am sure that Febo, at once, will call me from beyond. His tired soul will call me from the depth of night. And I know that I will go back, to follow him and my destiny. There we will depart under the moon, in tall grass, along the river, and Febo will be happy. And so, we shall leave as two old friends, two dear brothers, frolicking and rejoicing in that happy game of no return. (Malaparte, 2007, p. 49)

\section{References}

Arendt, H. (1973). The origin of totalitarianism. New York, Harvest Books.

Bauman, Z. (2005). Fiducia e paura nella città. Turim: Mondadori.

Bayly, C. A. (2009). The birth of the modern world: 1780-1914. Oxford: Blackwell.

Burkhert, W. Mito e Mitologia (Myth and mythology). Lisboa: Edições 70.

Cassirer, E. (1946). Language and myth. New York: Dover.

Cassirer, E. (1953). Language and myth, New York: Dover.

Colangelo, V. A. (2008). Cronistória di um conflito. L'esílio di Carlo Levi raccontato attraverso i documenti. Napoli: Scrittura \& Scrittore.

Columella. (1968). On agriculture [Rei rusticae]. London: Harvard University Press.

D’Amaro, S., \& Ritrovato, S. (2002). Carlo Levi e la letteratura di viaggio nel novecento. Foggia: Claudio Grenzi Editore.

Derrida, J. (1972). La dissemination. Paris: Editions du Seuil.

Dever, W. G. (2003). Who were the early Israelites and where did they come from? Michigan: Eerdman's.

di Donato, G. (Ed.). (1999). Carlo Levi: Il tempo e la durata in “Cristo si è fermato a Eboli." Roma: Fahrenheit 451.

di Donato, G., \& D’Amaro, S. (2003). Carlo Levi e il mezzogiorno. Foggia: Sergio G. Grenzi.

di Donato, G., \& D’Amaro, S. (2005). Un torinese del Sud: Carlo Levi: Una biografia. Milano: Baldini Castoldi Dalai.

Farina, W. (2014). Man writes dog: Canine themes in literature, law and folklore. Jefferson, NC: McFarland.

Fernandez, D. (1960). Il romanzo italiano. Milano: Lerici.

Galvano, R. (2004). Carlo Levi, narciso e la construione dela realta. Catania/Firenze: Leo S. Olschiki Editore.

Gat, A. (2015). War in Human Civilization. New York, University of Oxford Press.

Gibson, W. S. (2016). Metaphorical dogs in the latter Middle Ages: The dog of God and the hounds of hell. In L. D. Garland (Ed.). Our dogs, our selves: Dogs in medieval and early modern art, literature, and society (pp. 363-386). Boston and Leiden: Brill. https://doi.org/10.1163/9789004328617_017

Grandin, M. T. (2009). Animals in translation: Using the mysteries of autism to decode animal behavior. New York: Scribner.

Hobsbawm, E. J. (1987). The age of empire: 1875-1914. New York: Pantheon Books.

Hope, W. (2006). Curzio Malaparte: The narrative contract strained. Leicester: Troubadour.

Ibn al-Marzubān, M. (2016). Dogs in medieval Sufi literature. N. Hofer (Trans.). In L. D. Gelfand (Ed.), Our dogs, our selves: Dogs in medieval and early modern art, literature and society (pp. 78-96). Boston and Leiden: Brill.

Johns, C. (2008). Dogs, history myth, art. Hong Kong: Art Printing Press.

Joll, J. (1990). Europe since 1870: An international history (4th ed.). London: Penguin Books.

Kaiser, D. (2000). Italian politics and war: European conflict from Philip II to Hitler. Cambridge and London: Harvard University Press.

Laplantine, \& Nouss. (1997). La Métissage, Paris: Flamarion.

Latour, B. (1991). Nous n'avons jamais été modernes. Paris: Éditions La Découverte.

Lavaud, L. (1999). L'image. Paris: Éditions Flammarion.

Levi, C. (1964). Paura della libertá. Milano: G. Einaudi. 
Levi, C. (2002). Le tracce della memória. Roma: Donzelli Editore.

Levi, C. (2004). Le Ragione dei Topi. G. di Donato \& G. Sacerdoti (Eds.). Roma: Donzelli Editore.

Levi, C. (2010). Cristo si è fermato a Eboli. Roma: Newton Compton Editori.

Lippitt, A. M. (2000). Minneapolis: University of Minnesota Press.

Malaparte, C. (1966). Kaputt. Milano: Guarnati.

Malaparte, C. (1972). A Pele. Rio de Janeiro: Editora Civilizacao Brasileira.

Malaparte, C. (2002). The Volga rises in Europe. Edinburgh: Birlinn.

Malaparte, C. (2004). Fughe in Prigione. Milano: Arnaldo Mondadori Editore.

Malaparte, C. (2006). Febo, cane come me. Firenze: Emmebi Edizioni.

Malinowski, B. (1984). Magic, religion, science, and other essays. Westport: Greenwood Press.

Mangun, T. (2002). Dog years, human fears. In. N. Rothfels (Ed.), Representing animals (pp.35-47). Bloomington: Indiana University Press.

Markus, G. (2011). Culture, science, society: The constitution of cultural modernity. Leiden: Brill. https://doi.org/10.1163/ej.9789004202405.i-666

Martellini, L. (1977). Invito a la lettura su Malaparte. Varese: Mursia.

Martellini, L. (1996). Nel labirinto delle escritture, Vol. 17 di Studi e Saggi. Salerno: Salerno Editrice.

Miccinese, M. (1979). Come leggere Crito si é fermato. Varese: Mursia.

Moatti, C. (1997). La raison de Rome: Naissance de l'esprit critique à la fin de la Republique. Paris: Seuil. https://doi.org/10.14375/NP.9782020131155

Moscovici, S. (1994). La société contre nature. Paris: Essais, Editions Du Seuil.

Nigianni, C. (2014). The taste of living. In P. McCormack (Ed.), The animal catalyst: Towards a human theory (pp. X$\mathrm{X})$. London, Bloomsbury.

Nouss, M. L. (2001). Métissages: De Arcimboldo à Zombi. Paris: Éditions

Novek, J. (2012). Discipline and distance confined pigs in the factory farm Gulag. In A. Gross, \& A. Vallely (Eds.), Animal and human imagination: A companion of animal studies (pp. 121-150). New York: Columbia University Press.

Orwell, G. (1946). Animal farm. London: Penguin Books.

Plec, E. (Ed.). (2013). Perspectives on human-animal communication: Internatural Communication. New York, London, Routledge. https://doi.org/10.4324/9780203082935

Polanyi, K. (2001).The great transformation: The political and economic origin of our time. Boston: Bacon Press.

Poulantzas, N. (1972). Fascismo e ditadura. A III Internacional face ao fascismo, Vol. 1. Porto: Portucalense Editora.

Pugliese, S. (2001). Italian fascism and antifascism: A critical anthology. Manchester: Manchester University Press.

Pugliese, S. (2004). Fascism, antifascism and resistance in Italy:1919 to the present. Lanham: Rowman and Littlefield.

Rogers, L. J. (1998). Not only roars \& rituals: Communication in animals. Sidney: Allen \& Unwin.

Rogers, L. J., \& Kaplan, G. T. (2000). Songs, roars, and rituals: Communication in birds, mammals, and other animals (Second Printing). Harvard: Harvard University Press.

Schnapp-Gourbeillon, A. (1981). Lion, héros, masques: Las representations de l'animal chez Homère. Paris: G. Maspero.

Segalen, M. (2009). Rites et rituels contemporains: Domaines et approaches (2 ed.). Collection 128 Sociologie. Paris: Armand Colin.

Shukin, N. (2009). Animal capital. Rendering life in biopolitical times. Minneapolis: Univerity of Minnesota Press.

Sousa, J. P. (2004). Elementos de teoria e pesquisa da comunicação e da mídia. Florianópolis: Letras Contemporaneas.

Steiner, G. (2008) Animals and the moral community: Mental life, moral status, and kinship. New York: Columbia University Press. https://doi.org/10.7312/stei14234 
Steiner, G. (2010). Anthropocentrism and its discontents: The moral status of the animals in the history of western philosophy. Pittsburgh: University of Pittsburg Press.

Turner, V. (1969). The ritual process: structure and anti-structure. Chicago: Aldine.

Waldau P., \& Patton, K. (Eds.). (2006). A communion of subjects: Animals in religion, science, and ethics. New York, Columbia University Press.

\section{Copyrights}

Copyright for this article is retained by the author(s), with first publication rights granted to the journal.

This is an open-access article distributed under the terms and conditions of the Creative Commons Attribution license (http://creativecommons.org/licenses/by/4.0/). 